\title{
PENGARUH MEDIA TEBAK GAMBAR TERHADAP PENGETAHUAN JAJANAN SEHAT SISWA SDN 001 TERATAK KABUPATEN KAMPAR
}

\author{
Eka Roshifita Rizqi ${ }^{1}$, Yuni Sartika ${ }^{2}$ \\ Program Studi S1 Gizi \\ Universitas Pahlawan Tuanku Tambusai \\ ekarizqi4591@gmail.com¹, yunisartika978@gmail.com²
}

\begin{abstract}
A lot of students consumed snack that has imbalanced food quality and nutritional values. Preliminary study showed that 54,5\% students at 001 Teratak elementary school had low level of knowledge on healthy snack choice. Nutrition education is needed with efficient and simple method such as guessing picture. The aim of this study was to analyze the effect of guessing picture media method on student's knowledge on healthy snack choice in 001 Teratak Elementary School. This was quasy experimental study with a pre-test post-test control group design. 42 samples selected from 46 students in class 5 by purposive sampling technique with inclusion and exclusion criteria. Samples divided into intervention $(n=21)$ and control group $(n=21)$. The intervention group had guessing healthy snack choice picture while the control group had guessing ordinary pictures. Research variables were the level of knowledge in intervention and control group based on the value of the pretest and post-test. The results showed that there was significant increase of knowledge that were given nutritional education of healthy snack choice using guessing picture media method ( $p<0,05)$. There was significant difference of knowledge on intervention and control groups $(p<0,05)$. Finally, nutrition education with guessing picture media method can improve knowledge on healthy snack choice in elementary school students.
\end{abstract}

Keywords: Guessing Picture Media, Nutrition Education, Knowledge

\begin{abstract}
ABSTRAK
Banyak siswa mengonsumsi makanan jajanan yang memiliki kualitas makanan dan nilai gizi yang tidak seimbang. Studi pendahuluan di SDN 001 Teratak menunjukkan sebagian besar siswa $(54,5 \%)$ memiliki pengetahuan jajanan sehat yang masih kurang. Pendidikan gizi dibutuhkan untuk menunjang pengetahuan siswa dengan metode yang efisien dan sederhana seperti media tebak gambar. Tujuan dari penelitian ini adalah untuk menganalisis pengaruh media tebak gambar terhadap pengetahuan jajanan sehat siswa SDN 001 Teratak. Jenis penelitian ini adalah quasi eksperimental dengan rancangan pre-test post-test with control group. Sampel sebanyak 42 siswa dipilih dari populasi sebanyak 46 siswa kelas 5 dengan teknik purposive sampling dengan kriteria inklusi dan eksklusi. Sampel dibagi menjadi kelompok intervensi $(n=21)$ dan kelompok kontrol $(n=21)$. Kelompok intervensi mendapatkan media tebak gambar jajanan sehat dan kelompok kontrol mendapatkan media tebak gambar biasa. Variabel dalam penelitian ini adalah tingkat pengetahuan jajanan sehat kelompok intervensi dan kelompok kontrol berdasarkan nilai pre-test dan post-test. Hasil penelitian menunjukkan bahwa ada peningkatan pengetahuan jajanan sehat secara signifikan pada kelompok intervensi yang diberikan media tebak gambar jajanan sehat $(\mathrm{p}<0,05)$. Ada perbedaan pengetahuan jajanan sehat secara signifikan antara kelompok intervensi dengan kelompok kontrol $(p<0,05)$. Pendidikan gizi dengan metode menggunakan media tebak gambar dapat meningkatkan pengetahuan mengenai jajanan sehat pada siswa sekolah dasar.
\end{abstract}

Kata Kunci: Media Tebak Gambar, Pendidikan Gizi, Pengetahuan 


\section{PENDAHULUAN}

Siswa Sekolah Dasar

(SD)

menghabiskan seperempat waktunya untuk beraktivitas di sekolah. Mereka lebih banyak terpapar pada makanan jajanan. Hal yang perlu diperhatikan adalah pemilihan makanan jajanan yang baik untuk dikonsumsi sehingga tidak menimbulkan masalah kesehatan (Purnamasari, 2018).

Badan Pengawas Obat dan Makanan (BPOM) (2013) menemukan $14,7 \%$ makanan jajanan di tingkat sekolah dasar (SD) tidak memenuhi syarat karena kualitas mikrobiologis yang buruk dan masih mengandung bahan berbahaya yang dilarang digunakan dalam pangan seperti: boraks, formalin, pewarna tekstil dan pemanis buatan. Anak sekolah sering memilih makanan jajanan yang berbahaya karena belum memiliki pengetahuan yang cukup tentang makanan jajanan yang sehat (Triasari, 2015).

Pengetahuan yang baik diharapkan dapat mempengaruhi konsumsi makanan yang lebih baik. Pengetahuan termasuk didalamnya pengetahuan gizi dan jajanan yang dapat diperoleh melalui pendidikan formal maupun informal (Aisyah, 2015).

Hasil penelitian Briawan (2016) pada siswa SD kelas 5 dari 13 kabupaten/ kota di 8 provinsi Indonesia diketahui bahwa tingkat pengetahuan anak tentang jajanan yang baik sebesar 16,2\%. Praktik jajanan yang baik hanya meningkat $2,7 \%$ dan terjadi penurunan sebesar $13,4 \%$.

Untuk meningkatkan pengetahuan pada anak usia sekolah dalam pemilihan jajanan yang baik diperlukan pendidikan gizi. Pendidikan gizi dapat disampaikan menggunakan media atau alat peraga (Briawan, 2016). Salah satu media yang dapat digunakan dengan mudah dan efisien namun tetap menyenangkan adalah media tebak gambar.

Berdasarkan survey pendahuluan di SDN 001 Teratak pada 11 siswa diperoleh hasil $18,1 \% \quad(2$ orang $)$ memiliki pengetahuan baik, $27,2 \%$ (3 orang) memiliki pengetahuan cukup dan 54,5\% (6 orang) memiliki pengetahuan rendah. Pihak sekolah sudah melarang pedagang berjualan di luar sekolah namun hanya dipatuhi beberapa minggu, selanjutnya kembali berjualan di gerbang sekolah. Berdasarkan hal tersebut penulis merasa perlu melakukan penelitian "Pengaruh Media Tebak Gambar terhadap Pengetahuan Jajanan Sehat Siswa SDN 001 Teratak Kabupaten Kampar”.

\section{METODE}

Jenis penelitian ini adalah quasi eksperimental menggunakan rancangan pretest post-test with control group. Penelitian ini dilakukan pada bulan Juli 2019 di SDN 001 Teratak, Kecamatan Rumbio Jaya, Kabupaten Kampar, Riau.

Sampel sebanyak 42 siswa kelas V SDN 001 Teratak dipilih dari populasi sebanyak 46 siswa menggunakan teknik purposive sampling. Sampel dipilih dengan kriteria inklusi siswa kelas V di SDN 001 Teratak dan dapat hadir dikelas pada saat penelitian. Kriteria eksklusi dalam penelitian ini adalah siswa yang sedang sakit dan tidak bersedia menjadi subjek penelitian. Persetujuan siswa dalam mengikuti prosedur penelitian dibuktikan dengan informed consent. Sampel dibagi menjadi kelompok intervensi $(n=21)$ dan kelompok kontrol $(\mathrm{n}=21)$.

Dilakukan pre-test pada kedua kelompok. Pengukuran pengetahuan jajanan sehat menggunakan kuesioner pertanyaan pilihan berganda. Hasil pengukuran dikelompokkan menjadi baik (76-100\%), cukup (56-76\%) dan kurang $(<56 \%)$ (Lapau, 2013).

Kelompok intervensi mendapat pendidikan gizi menggunakan media tebak gambar mengenai jajanan sehat sedangkan kelompok kontrol mendapatkan paparan media tebak gambar biasa. Pendidikan gizi diberikan sebanyak 1 kali dalam 1 minggu, baik pada kelompok intervensi maupun 
kelompok kontrol. Setelah itu dilakukan post-test menggunakan kuesioner pertanyaan pilihan berganda yang sama diberikan pada saat pre-test. Data dianalisis menggunakan uji paired sample t-test dan independent t-test.

\section{HASIL}

Berdasarkan karakteristik subjek penelitian diketahui bahwa sebagian besar berjenis kelamin perempuan (52\%). Hasil pre-test pengetahuan jajanan sehat pada kelompok intervensi dapat dilihat pada Tabel 1, sebagian besar memiliki tingkat pengetahuan cukup $(76,1 \%)$, begitu pula dengan kelompok kontrol (42,8\%). Hasil post-test pengetahuan gizi pada kelompok intervensi dapat dilihat pada Tabel 2, sebagian besar memiliki tingkat pengetahuan baik $(95,2 \%)$, sedangkan pada kelompok kontrol sebagian besar tingkat pengetahuannya cukup $(57,1 \%)$.

Tabel 1. Distribusi Pre-test Pengetahuan Jajanan Sehat Siswa

\begin{tabular}{ccccc}
\hline Tingkat & \multicolumn{4}{c}{ Pre-test } \\
\cline { 2 - 5 } Pengetahuan & Kontrol & \multicolumn{3}{c}{ Intervensi } \\
\cline { 2 - 5 } & $\mathbf{n}$ & $\%$ & $\mathbf{n}$ & $\mathbf{\%}$ \\
\hline Baik (76-100\%) & 4 & 19 & 4 & 19 \\
Cukup $(56-76 \%)$ & 9 & 42,9 & 16 & 76,2 \\
Kurang $(<56 \%)$ & 8 & 38,1 & 1 & 4,8 \\
\hline Total & 21 & 100 & 21 & 100 \\
\hline
\end{tabular}

Tabel 2. Distribusi Post-test Pengetahuan Jajanan Sehat Siswa

\begin{tabular}{ccccc}
\hline Tingkat & \multicolumn{4}{c}{ Post-test } \\
\cline { 2 - 5 } Pengetahuan & Kontrol & \multicolumn{3}{c}{ Intervensi } \\
\cline { 2 - 5 } & $\mathbf{n}$ & $\%$ & $\mathbf{n}$ & $\%$ \\
\hline Baik $(76-100 \%)$ & 7 & 33,3 & 20 & 95,2 \\
Cukup $(56-76 \%)$ & 12 & 57,1 & 1 & 4,8 \\
Kurang $(<56 \%)$ & 2 & 9,5 & 0 & 0 \\
\hline Total & 21 & 100 & 21 & 100 \\
\hline
\end{tabular}

Berdasarkan hasil uji paired sample ttest pada Tabel 3 diketahui bahwa ada peningkatan pengetahuan secara signifikan pada kelompok intervensi $(\mathrm{p}<0,05)$. Rerata skor pengetahuan gizi pada kelompok intervensi setelah diberikan media tebak gambar jajanan sehat lebih tinggi $(89,61 \pm 7,66)$ dibandingkan saat pre-test $(65,33 \pm 9,02)$.

Berdasarkan hasil uji independent t-test pada Tabel 4 diketahui bahwa ada perbedaan pengetahuan secara signifikan pada kelompok intervensi dan kelompok kontrol $(p<0,05)$ setelah diberikan media tebak gambar jajanan sehat.

Tabel 3. Pengaruh Media Tebak Gambar terhadap Pengetahuan Jajanan Sehat Siswa

\begin{tabular}{cccc}
\hline Kelompok & Pengetahuan & Rerata \pm SD & $\begin{array}{c}\text { p- } \\
\text { value }\end{array}$ \\
\hline \multirow{2}{*}{ Intervensi } & Pre-test & $65,33 \pm 9,02$ & $0,00^{*}$ \\
& Post-test & $89,61 \pm 7,66$ & \\
\multirow{2}{*}{ Kontrol } & Pre-test & $62,23 \pm 12,85$ & 0,64 \\
& Post-test & $67,28 \pm 11,12$ & \\
\hline
\end{tabular}

Uji paired sample t-test; $*=$ bermakna $(\mathrm{p}<0,05)$; $\mathrm{SD}=$ standar deviasi

Tabel 4. Pengetahuan Jajanan Siswa Kelompok Intervensi dan Kontrol

\begin{tabular}{|c|c|c|c|}
\hline Pengetahuan & Kelompok & Rerata \pm SD & $\begin{array}{c}\text { p- } \\
\text { value }\end{array}$ \\
\hline Pre-test & $\begin{array}{c}\text { Intervensi } \\
\text { Kontrol }\end{array}$ & $\begin{array}{c}65,33 \pm 9,02 \\
61,24 \pm 12,85\end{array}$ & 0,37 \\
\hline Post-test & $\begin{array}{l}\text { Intervensi } \\
\text { Kontrol }\end{array}$ & $\begin{array}{c}88,86 \pm 7,82 \\
68,33 \pm 11,60\end{array}$ & $0,00 *$ \\
\hline
\end{tabular}

\section{PEMBAHASAN}

Dari penelitian ini diketahui bahwa ada peningkatan pengetahuan jajanan sehat secara signifikan pada kelompok intervensi, namun tidak pada kelompok kontrol. Ada perbedaan pengetahuan jajanan sehat pada kelompok kontrol dan kelompok intervensi setelah diberikan pendidikan gizi menggunakan media tebak gambar.

Hal ini sejalan dengan penelitian Septiana dan Suaebah (2018) ditemukan peningkatan pengetahuan dari sebelum diberikan media kartu bergambar sebesar 89,6 menjadi 97,4. Ada perbedaan nilai pengetahuan sebelum dan sesudah intervensi menggunakan media kartu bergambar $(\mathrm{p}<0,05)$. 
Penelitian mengenai pengaruh pendidikan keamanan jajanan menggunakan media komik bergambar terhadap pengetahun gizi siswa menunjukkan bahwa tidak ada pengaruh signifikan antara pengetahuan pre-test dan post-test pada kelompok kontrol (Rosita, 2017).

Pendidikan gizi dapat membantu seseorang dalam menerapkan hidup sehat dengan cara memperoleh informasi dalam pemilihan makanan yang tentunya berguna bagi tubuh (Supariasa, 2012). Pendidikan gizi diperlukan untuk meningkatkan pengetahuan terutama mengenai pemilihan jajanan sehat pada anak sekolah.

Pengetahuan merupakan hasil tahu dari seseorang terhadap objek melalui indera yang dimilikinya (mata, hidung, telinga dan sebagainya). Sebagian besar pengetahuan diperoleh melalui indera pendengaran (telinga) dan indera penglihatan (mata) (Notoatmodjo, 2010).

Pengetahuan awal seseorang sebelum menerima intervensi menentukan seberapa tinggi kenaikan skor pengetahuan setelah intervensi diberikan. Peningkatan pengetahuan sering dianggap menjadi langkah pertama dalam mempengaruhi perilaku kesehatan (Rosita, 2017).

Efektifitas pembelajaran akan terlaksana jika memanfaatkan media pembelajaran dengan baik. Pemakaian media pembelajaran dalam proses belajar mengajar dapat membangkitkan keinginan dan minat yang baru, membangkitkan motivasi dan rangsangan kegiatan belajar dan bahkan membawa pengaruh psikologi terhadap siswa. Media gambar memegang peran yang sangat penting dalam proses belajar karena dapat memperlancar pemahaman dan memperkuat ingatan (Saloso, 2011).

Pendidikan gizi menggunakan media tebak gambar dapat meningkatkan pengetahuan gizi siswa terutama siswa SD karena media ini mudah diterapkan pada siswa SD yang memiliki ketertarikan yang tinggi pada permainan. Permainan yang mudah, bermanfaat dan menyenangkan merupakan kunci terpenting dalam menyelesaikan permainan. Siswa dengan sendirinya akan termotivasi untuk mengikuti apa yang sedang dijelaskan karena merasa tertantang untuk mengetahui gambar apa yang dibawa oleh pendidik (Yulianto, 2017).

\section{KESIMPULAN}

Ada peningkatan pengetahuan jajanan sehat secara signifikan pada kelompok intervensi. Ada perbedaan pengetahuan jajanan sehat pada kelompok kontrol dan kelompok intervensi setelah diberikan pendidikan gizi menggunakan media tebak gambar.

Media tebak gambar ini dapat diaplikasikan sebagai media baru dalam proses pembelajaran yang tidak hanya memberikan informasi tetapi juga hiburan kepada siswa. Hal ini dilakukan agar mampu meningkatkan minat siswa memahami gizi terutama pemilihan jajanan sehat dengan lebih baik lagi.

\section{DAFTAR PUSTAKA}

Aisyah (2015) Hubungan Pengetahuan dan Sikap Anak terhadap Perilaku Pemilihan Makanan Jajanan yang Sehat di SD Muhammadiyah Karangasem Surakarta. Skripsi. Surakarta: Universitas Muhammadiyah Surakarta.

BPOM (2013) Pedoman Pangan Jajanan Anak Sekolah untuk Pencapaian Giz Seimbang. Jakarta: Badan Pengawas Obat dan Makanan Republik Indonesia.

Briawan, D. (2016) 'Perubahan Pengetahuan, Sikap dan Praktik Jajanan Anak Sekolah Dasar Peserta Program Edukasi Pangan Jajanan', Jurnal Gizi Pangan, 11(3), pp. 210210.

Lapau, B. (2013) Metode Penelitian 
Kesehatan: Metode Ilmiah Penulisan Skripsi, Tesis dan Disertasi. Jakarta: Yayasan Pustaka Obor Indonesia.

Notoatmodjo (2010) Promosi Kesehatan Teori dan Aplikasi. Jakarta: Rineka Cipta.

Purnamasari (2018) Panduan Gizi dan Kesehatan Anak Sekolah. Yogyakarta: Penerbit Andi.

Rosita, W. (2017) Pengaruh Pendidikan Keamanan Jajanan Menggunakan Media Komik terhadap Pengetahuan Gizi Siswa SDN 003 Bangkinang Kota. Skripsi. Bangkinang: Universitas Pahlawan Tuanku Tambusai.

Saloso, I. (2011) Pengaruh Media Audio (Lagu Anak-anak) dan Media Visual (Kartu Bergambar) terhadap Pengetahuan Gizi (PUGS dan PHBS) serta Tingkat Penerimaannya pada Anak Usia Sekolah Dasar Negeri di Kota Bogor. Skripsi. Bogor: Institut Pertanian Bogor.

Septiana and Suaebah (2018) 'Edukasi
Media Kartu Bergambar Berpengaruh terhadap Pengetahuan dan Sikap Anak dalam Pemilihan Jajanan Sehat di SD Negeri Pontianak Utara', Pontianak Nutrition Journal, 1(2), pp. 56-59.

Supariasa (2012) Pendidikan dan Konsultasi Gizi. Jakarta: EGC.

Triasari, R. (2015) Hubungan Pengetahuan dan Sikap Mengenai Jajanan Aman dengan Perilaku Memilih Jajanan pada Siswa Kelas V SD Negeri Cipayung 2 Kota Depok. Skripsi. Jakarta: Universitas Islam Negeri Syarif Hidayatullah Jakarta.

Yulianto (2017) Permainan Tebak Gambar Berbasis Pretend Play sebagai Solusi Peningkatan Daya Ingat Anak. Available at: https://www.academia.edu/34797154/p ermainan_tebak_gambar_berbasis_pret end_play_sebagai_solusi_peningkatan_ daya_ingat_anak_usia_dini. 